\title{
Progressive release of security to incentivise and fund closure
}

\author{
KA Bocking Golder Associates Ltd., Canada \\ K Lewis Lupin Mines Incorporated, Canada
}

\begin{abstract}
Most active mines in Canada now have closure plans in place and have posted some form of financial security with the government. At the same time, the number of inactive mines that have fully implemented final closure (as opposed to staying in 'care and maintenance') is relatively small. In some cases, this hesitancy to complete closure is related to uncertainty as to how and when the security will be returned to the mining company.
\end{abstract}

This paper describes a case history where cooperation between government, regulators, and a mining company resulted in agreement to progressively release the financial security in stages in response to closure work that had been competed during operations, interim care and maintenance, and final closure stages. This provided an incentive to proceed with the completion of the final closure measures and it also provided a flow of cash (or credit release) to fund final closure of a long inactive property.

It is suggested that progressive release of closure financial security could mobilise large amounts of capital to implement final closure on numerous long inactive mine sites.

Keywords: mine closure, reclamation, mine closure regulations, financial security, Nunavut

\section{Introduction}

In Canada, the number of mines that have been fully and completely closed is relatively small. As a result, there is currently a large inventory of inactive mines which are not abandoned, but which have not been fully closed either. These unclosed mines are typically said to be on 'care and maintenance'. There is a risk that mines in this category could eventually be abandoned, possibly in association with the bankruptcy of the mining company.

Since the 1990s, all of the jurisdictions in Canada have required mines to post a reclamation security, with the provision that, should a mine be abandoned, the responsible government agency can seize the security and use it to implement closure. There are recent examples of this happening in each of Canada's three northern territories. This is not a satisfactory outcome. Firstly, the actual costs of implementing closure have often exceeded the amount of the security. Secondly, even where the security is adequate, the cost for governments to implement closure by mobilising third-party contractors to the mine site will almost certainly be higher than the costs for the mining company to administer the work themselves at the end of mining making use of their own equipment and manpower.

Realistically, the only way that society's broader need to see all mines properly closed will be met is if the mining companies themselves close their own sites. It is therefore important that mining companies be encouraged to move their inactive properties from care and maintenance to full closure. Taken together, the reclamation security amounts that are held against all of the active or inactive mines in Canada represents a very large pool of capital (or credit). For example, the province of Ontario, one of the largest of the 13 mining jurisdictions in Canada, currently holds security in the amount of CAD 2.003 billion (Ontario Ministry of Energy Northern Development and Mines 2019). This pool of capital could potentially provide a strong incentive for mining companies to implement final closure. The incentive effect would, however, be diminished if the conditions for the release of the security are not clear, or if the security is to be held in total until the closure is fully complete and 'signed off'. (The latter situation would require the management of the mining company 
to authorise an expenditure which may amount to tens of millions of dollars to close a property that has no enduring value as a mine. It is understandable that they may be reluctant to do so given the current relative scarcity of mining investment capital. This suggests that mining companies, government, and regulators need to agree on a transparent mechanism to release the reclamation security progressively over the period during which the closure measures are being implemented.

This paper describes the case history of the closed Lupin Mine, where cooperation between government, regulators, and the mining company has resulted in an agreement to progressively release the financial security in stages in response to closure work that has been completed during the operations and the interim care and maintenance stages, or which will be completed progressively during the final closure stage.

\section{$2 \quad$ Lupin Mine}

\subsection{Location and setting}

Lupin Mine is an inactive underground gold mine and mill in Nunavut Territory in Canada. It is owned by Lupin Mines Incorporated (LMI); a wholly owned indirect subsidiary of Mandalay Resources Corporation.

The mine is located near the western boundary of Nunavut, in the Kitikmeot Region, about $86 \mathrm{~km}$ south of the Arctic Circle and $220 \mathrm{~km}$ south of the Arctic Ocean. The site is normally accessed by air using a landing strip onsite. There are no all-weather roads to the site, so heavy equipment or freight must be transported by a winter road, which could potentially be operated between the months of February and April. Over much of their lengths, winter roads make use of carefully maintained ice surfaces on lakes to support truck traffic. The Tibbitt to Contwoyto winter road extends about $570 \mathrm{~km}$ from near Yellowknife, Northwest Territory, to the site. Since 2008, construction of the winter road beyond the Ekati Diamond Mine (Km 405) has occurred occasionally, not annually. The Lupin Mine spur road has been inactive for several years but can be reactivated to allow for the delivery or removal of bulk items. Winter road routing is shown on Figure 1.

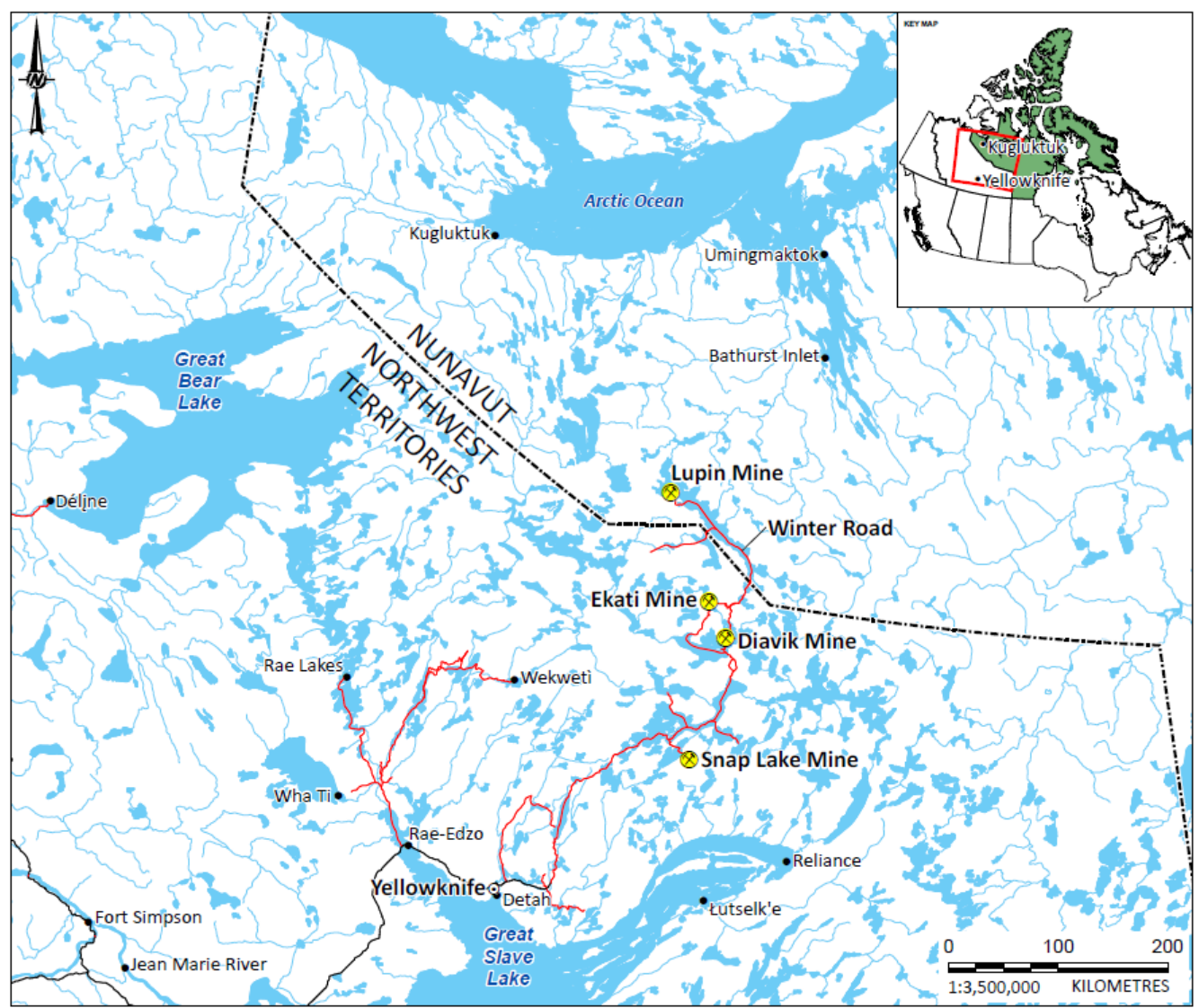

Figure 1 Location and access to Lupin Mine 
The mine is located in a treeless tundra setting in a region of deep continuous permafrost. The climate is classed as semi-arid subarctic, with an average annual precipitation of approximately $300 \mathrm{~mm}$. August is the wettest month with average rainfall of $59.8 \mathrm{~mm}$. The annual average temperature is $-10.9^{\circ} \mathrm{C}$; July is the warmest month with average temperature of $11.7^{\circ} \mathrm{C}$, whereas January is the coldest month with a monthly average of $-29.7^{\circ} \mathrm{C}$.

\subsection{Regulatory framework for mine closure in Nunavut}

Nunavut is the newest of Canada's three territories. It was formed on 1 April 1999 with the implementation of the Nunavut Agreement, which split the former Northwest Territories roughly in half. Lands to the west of the treeline remained in the reduced Northwest Territories and the barren lands to the east formed Nunavut. Nunavut has a land area of more than $2 \mathrm{M} \mathrm{sq} \mathrm{km}$ and a population of only about 36,000 people. Inuit comprise more than $83 \%$ of the population (Kusugak 2019). Under the agreement, the Inuit sold about $82 \%$ of their land to the Canadian federal government and retained title to the remaining $18 \%$. Inuit Owned Lands (IOL) include control of surface and/or subsurface (mineral) rights.

The mine leases of Lupin Mine are entirely on federal crown land, which is administered by Crown Indigenous Relations and Northern Affairs Canada (CIRNAC). Within the Kitikmeot Region of Nunavut, Inuit beneficiaries are represented by the Kitikmeot Inuit Association (KIA). The KIA is the entity responsible for defending, preserving, and promoting social, cultural, and economic benefit to Inuit in the region, as well as lands management for $\mathrm{IOL}$ and Inuit Water Rights. During all phases (i.e. operation, care and maintenance, implementation of final closure and post-closure), the mine requires a regulatory licence termed a 'Type $A$ Water Licence' (water licence), which is administered by the Nunavut Water Board (NWB). One of the conditions of all water licences is to have in place an approved mine closure plan. Prior to start-up, a new mine must have an approved 'Preliminary Closure and Reclamation Plan' (PCRP). During operations and during post-operational care and maintenance, the closure plan is termed an 'Interim Closure and Reclamation Plan' (ICRP). There is a requirement to renew and update ICRPs periodically, typically on a threeyear cycle. Prior to the implementation of final closure, a 'Final Closure and Reclamation Plan' (FCRP) must be submitted and approved.

Associated with each mine closure plan is the requirement to provide reclamation security in an acceptable form and amount. The amount of the security is meant to be sufficient to pay entirely for the final closure and remediation of a mine site, on the assumption that the mine may be abandoned by the owner. In other words, the costs are meant to represent what it would cost a government agency to assume control of the mine site and to close it using third-party contractors.

Mines in Nunavut and the Northwest Territories are required to prepare their estimates of reclamation security using a spreadsheet costing tool called RECLAIM. This tool was originally commissioned by Indigenous and Northern Affairs Canada (INAC) (the predecessor name of CIRNAC), and it has subsequently also been adopted by the NWB, as well as the water boards of the Northwest Territories. The current guidelines for the use of the tool are provided in Indigenous and Northern Affairs Canada (2017). The NWB also require that closure plans take into account the 'Mine Site Reclamation Policy' (Indian and Northern Affairs Canada 2002) and also that the closure cost estimate should be assessed by a third-party.

Unlike some jurisdictions, the amounts of reclamation securities associated with mines and proposed mines in Canada's three territories are public information. This recognises that the public has an interest because, if a mine is abandoned, it will ultimately be managed by the government, and any costs for reclamation (net of the reclamation security) will be borne by the taxpayer.

Remediation of the Lupin Mine site will follow a FCRP. The FCRP requires approval pursuant to the Nunavut Planning and Project Assessment Act (2013) and Nunavut Waters and Nunavut Surface Rights Tribunal Act (2002) and associated Nunavut Water Regulations (2013). 


\section{$3 \quad$ Mine description}

\subsection{Mine history}

Lupin Mine is an underground gold mine that was in operation from 1982 to 2005 with temporary suspensions of activities between January 1998 and April 2000, and again between August 2003 and March 2004. The mine resumed production in March 2004 until February 2005. Production ceased in 2005; at that time, the site was put under care and maintenance. No active mining has occurred since that time. Ownership of the mine has passed through several companies since 2005.

Lupin Mine has never been abandoned; rather LMI has had crews onsite during the summer seasons since 2006 treating and releasing water as necessary and also carrying out routine maintenance and monitoring as required. LMI has also undertaken a significant number of progressive reclamation measures as permitted under the approved ICRPs that were in effect. Until recently, the plans were actually termed 'Interim Abandonment and Reclamation Plans', which seems inconsistent with the concept of having the closure undertaken by the mine itself. For several years, it was hoped that the mine could be reopened at some time in the future. The decision to proceed with complete and final closure of the site was made in 2017.

\subsection{Mine description}

Out of necessity, Lupin Mine was designed and operated as a largely self-sufficient, fly-in-fly-out facility. The mine site included an underground mine, a mill, a tailings containment area (TCA), borrow pits and quarries, an extensive camp facility, a diesel powered generating station, a large fuel tank farm, several maintenance shops and warehouses, and a 1,950 m airstrip and several laydown areas. It also had waste management facilities including a TCA water treatment facility, a sewage lagoon system, a solid non-hazardous waste landfill, an incinerator system, and more recently a bioremediation pad for hydrocarbon contaminated soils.

The Lupin Mine underground workings include a 1,210 m vertical shaft and a decline drift, or ramp, to a depth of $1,560 \mathrm{mbgl}$. A secondary hoist system (a winze) was installed in 2001 allowing hoist access to $1,340 \mathrm{~m}$. The final mine depth is $1,550 \mathrm{mbgl}$. There are also two other shafts open to surface: a fresh air raise and an exhaust raise. Incorporated into the underground facility were maintenance shops, an electrical shop, and a primary crushing station. The orebody was nearly vertical and the crown pillars were mined out to surface in three zones.

The tailings from Lupin Mine milling and ore processing operations were deposited in the TCA. The TCA is located approximately $6 \mathrm{~km}$ south of the Lupin Mine and covers a total area of about 361 ha. Containment is provided by eight perimeter dams and by six internal dams. The TCA includes five solids retention cells and two polishing ponds (Pond 1 and Pond 2). Pond 1 acts as a buffering pond to manage the water chemistry. A water treatment plant was formerly located on J-Dam between Ponds 1 and 2 and was used during operations to treat the water in Pond 1 prior to discharge into Pond 2. Pond 2 is the last point of control prior to discharge into the receiving environment. The total areal extent of the tailings was about 152 ha. The tailings have been shown by various studies to be capable of generating acid upon oxidation.

Waste rock from underground was generally used throughout the site as pads, roadbed materials, in airstrip stabilisation, underground backfill, and laydown yards or for other purposes such as building foundation preparation. The estimated volume of waste rock on surface is about $1,000,000 \mathrm{~m}^{3}$. Environmental site assessments in 2006 and 2017 indicated that up to $67 \%$ of the waste rock can be classified as potentially acid generating (PAG) and that PAG samples were distributed across the site. The mine operations did not produce any stockpiles of overburden or unprocessed low-grade ore.

\subsection{Progressive reclamation activities}

By definition, progressive reclamation comprises closure related activities that are undertaken while a mine is still in operation. At Lupin Mine, closure of several redundant facilities was completed before the mine shut down in 2005. In effect, progressive reclamation at Lupin Mine started in 1988. 
Also, a test plot program was undertaken to develop and verify a method for covering the exposed tailings in the TCA. In 2006, approval was granted for a plan (Kinross Gold Corporation 2006) to close the TCA in part by covering the exposed PAG tailings with a $1 \mathrm{~m}$ thick granular cover. While the cover will thaw completely near the end of each summer season, it is designed to remain saturated near the bottom of the layer (Holubec Consulting Inc. 2005). This saturated zone will greatly limit the flux of oxygen into the underlying tailings. Close to 40 ha of tailings cover was completed before the mine shut down.

Two of the three mined out crown pillar zones were stabilised by backfilling them with cemented paste tailings or waste rock.

\subsection{Post-operational reclamation activities}

Since the shut down in 2005, the site has been continuously under care and maintenance. It has never been in an abandoned condition. Following shut down, a substantial number of closure activities have been undertaken on a seasonal basis. Herein, these activities are described as post-operational activities.

Placement of the TCA cover has continued since the mine shutdown. As of the end of the 2017 construction season, sandy gravel material from an esker borrow area had been placed over approximately 131 ha of the exposed tailings. As of the end of 2017, only about 20.9 ha of exposed tailings (about $14 \%$ of the total area) remained to be covered. LMI intends to continue placement of the cover as part of its ongoing care and maintenance activities, as approved under the current ICRP. In recent years, an enhanced instrumentation system (including thermistor strings and oxygen sensors) has been installed in the TCA to monitor the performance of the granular cover. Repairs were completed on one of the internal dams, which had been damaged by wave erosion.

The winze and underground mine equipment were removed from site. All hazardous materials were removed from the underground workings. Any mobile equipment left (disposed of) in the underground workings was drained of fluids.

All metallurgical reagents used during operation in the Mill Complex (except for lime, which is still used for water treatment) have been shipped offsite during the current care and maintenance phase. The mill was given a complete wash-down with the intent of gold recovery (visible gold that settles within the system) and any residual contaminants (from chemical use) were buried in the TCA.

Hazardous waste materials were removed from the facilities, consolidated, and shipped offsite for disposal in licenced facilities. Shipment occurs opportunistically as backhauls on freight aircraft. Since 2005, shipment of at least 154,000 $\mathrm{kg}$ has been documented.

Numerous fuel tanks and buried pipelines have been decommissioned and removed. A pilot 'landfarm' facility was constructed to bioremediate hydrocarbon contaminated soils. Operation began in 2017.

An extensive Phase 1 and 2 environmental site assessment was completed. This included sampling and geochemical testing of the waste rock material across the mine site. In addition, a study was completed to identify and estimate the quantity of asbestos containing materials, which will require special handling during demolition.

Subsequent to the cessation of operations in 2005, the only water which accumulates in Pond 2 of the TCA has been local runoff from the TCA watershed. The water is mildly acidic because it as been in contact with tailings that have not yet been covered. The water is treated by simple lime addition and then it is released by syphoning it over Dam 1 to the environment. Since 2005, there have been seven water treatment campaigns to reduce the volume of water within the TCA. These campaigns have occurred in 2005, 2009, 2012, 2015, 2017, and 2018.

Over the years, LMI has submitted several reports to the NWB documenting the reclamation work that has been completed. 


\section{$4 \quad$ Closure plans and implementation}

Reclamation work completed to date on the Lupin Mine site has complied with the applicable version of the ICRP which was in place at the time. The most recent ICRP was prepared in October 2017 and approved on 20 July 2018.

Implementation of final closure measures will require approval of a FCRP under the water licence. LMI submitted an FCRP to the NWB regulatory agency on 20 July 2018, and it is currently undergoing the approvals process. The FCRP is necessarily more detailed than the current ICRP and it also involves some proposed modifications to the closure measures proposed in the ICRP. The closure measures that are presently being implemented at the site are those that are approved under the current ICRP. Modified closure measures, as per the FCRP, would only be implemented after the FCRP is approved by the NWB.

The FCRP also includes a revised estimate of the reclamation security, however, the new estimate will only come into effect once the FCRP and the new estimate are specifically approved under the water licence renewal process. The current reclamation security amount is based upon the estimate presented in the 2017 ICRP.

While some preparatory work will be undertaken onsite during 2019, the intensive closure work (such as building demolition, site clean-up, and completion of soil covers) is now expected to begin in 2020 after a fleet of construction equipment is mobilised to the site over the winter road in February 2020. The site work is expected to be completed in 2021 so that the construction equipment (together with salvaged equipment, scrap, and any remaining hazardous waste materials) can be demobilised by ice road in February 2022.

\section{$5 \quad$ Progressive release of security}

The liability associated with the closure of a mine should not be seen as a constant value over the entire life of the mine. Rather, as illustrated schematically in Figure 2 , it will vary continuously through the various stages of the mine life: development, operation, post-operation care and maintenance, closure implementation, and post-closure. Recently, in approving PCRPs for proposed new mines in Canada's territories, government, and regulators (CIRNAC and the territorial water boards) have recognised this and have approved submittal of the reclamation security in several discrete stages as the mines develop. The principle followed is that the security posted at the beginning of any particular stage must be sufficient to close the mine if it were to be abandoned at the end of that stage.

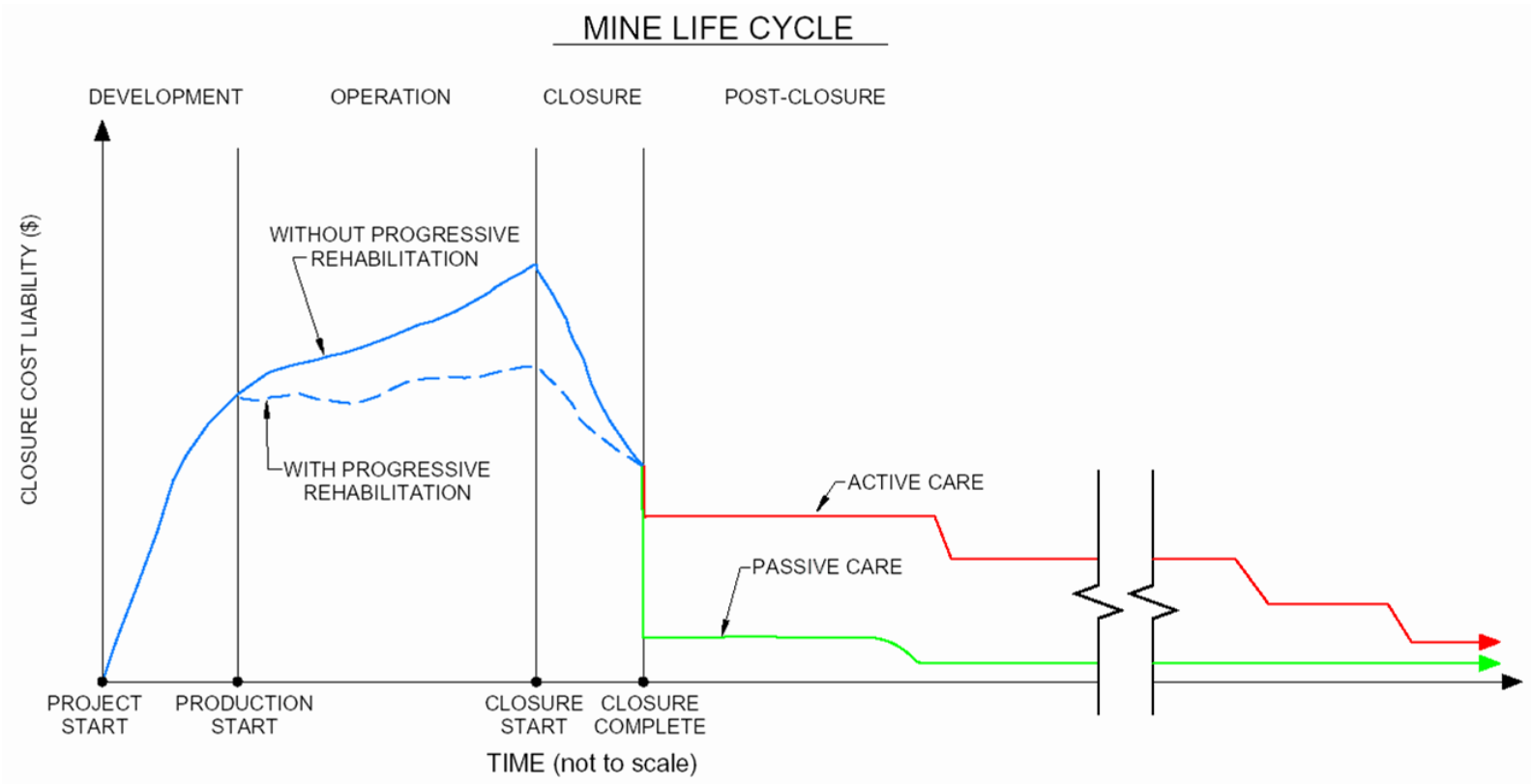

Figure 2 Schematic of variation in mine closure liability over a mine lifecycle 
The rationale for increasing the reclamation security in stages as a new mine is developed and goes into operation can also be applied to a closed mine which is undergoing progressive reclamation followed by final closure. In such a case, it is reasonable to refund the reclamation security in stages as closure work is completed.

The current reclamation security amount pertains to the most recently approved ICRP, which is dated 18 October 2017. In 2016, LMI arranged for their reclamation security estimate to be compiled into the RECLAIM costing tool. INAC disputed the company's estimate and the NWB arranged for a third-party consultant to review the disputed estimates. On 28 March 2017, the NWB issued Amendment No. 1 to the Lupin Mine water licence to set the amount of reclamation security required under Part $C$ of the water licence at CAD 34.65 million. This amendment was subsequently approved by the federal minister responsible for CIRNAC on 12 May 2017. This amount currently forms the starting point for any future adjustments to the security amount.

On 18 April 2018, the NWB issued Amendment No. 2, which reduced the reclamation security amount to $\$ 29.305$ million. The specific reasons for the decision for a security reduction of CAD 5.34 million were documented in Nunavut Water Board (2018). It was further noted:

"The NWB also recognizes that $L M I$ is committed to, and has substantive plans to, reinvest any security returned to $L M I$ to undertake reclamation activities in the field season ahead. .... In this case, the Board notes that the activities of LMI on-site planned for this year will further reduce the ultimate cost to reclaim the site. Obviously, it is in the interests of all parties, including the public in general and adjacent communities specifically that LMI be in a position to undertake planned and orderly reclamation, rather than allowing site conditions to deteriorate."

Amendment No. 2 was accepted in recognition of reclamation work that had been completed as of 1 July 2017. LMI subsequently requested a further reduction in the reclamation security amount for additional reclamation work that had been completed between 1 July 2017 and 5 July 2018. In December 2018, the NWB and CIRNAC agreed to a further security reduction of CAD 3.197 million.

In consideration of the funds released from the reclamation security, LMI has recently engaged a contractor to undertake the final closure work. The incremental release of reclamation security that has taken place to date has been instrumental in LMI's decision to proceed with final closure work. It has also been agreed in principle that there will be periodic releases of security over the next three years as the final closure work is progressively completed. The amount of each of the security releases will be evaluated by adjusting the quantities in the RECLAIM estimate, in a manner similar to the calculation of progress payments for construction. Furthermore, the NWB has agreed to streamline the progressive release process, such that releases can be made with the administrative review and approval by CIRNAC, without requiring multiple separate amendments to the Lupin Mine water licence each time.

\section{Conclusion}

Lupin Mine provides an example where cooperation between government, regulators, and a mining company has resulted in agreement to progressively release the reclamation security in stages in response to closure work that has been competed during operations, interim care and maintenance, and final closure stages. This has provided an incentive to proceed with the completion of the final closure measures and it also provided a flow of cash (or credit release) to help fund final closure of the long inactive property.

It is suggested that progressive release of closure financial security could mobilise large amounts of capital to implement final closure on numerous long inactive mine sites. That is a much more satisfactory outcome than leaving inactive mines sites in a state of 'care and maintenance' which leaves them vulnerable to eventual abandonment. 


\section{Acknowledgement}

The authors gratefully acknowledge the review and assistance of Dionne Filiatrault, P. Eng., especially regarding the description of the regulatory process in Nunavut. We also acknowledge the efforts of our colleagues on the broader team that prepared the FCRP for the closure of Lupin Mine.

\section{References}

Government of Canada 2002, Nunavut Waters and Nunavut Surface Rights Tribunal Act, S.C. 2002, c. 10, https://laws-lois.justice.gc.ca /eng/acts/N-28.8/FullText.html

Government of Canada 2013, Nunavut Planning and Project Assessment Act, S.C. 2013, c. 14, s. 2, https://laws-lois.justice.gc.ca /eng/acts/N-28.75/FullText.html

Government of Canada 2013, Nunavut Water Regulations, SOR/2013-69, https://laws-lois.justice.gc.ca/eng/regulations/SOR-201369/FullText.html

Holubec Consulting Inc. 2005, Lupin Operation - Closure Plan for Tailings Containment Area, January 2005.

Indian and Northern Affairs Canada 2002, Mine site reclamation policy for Nunavut, Catalogue No. R2-208/2002-iE, Ottawa, Canada. Indigenous and Northern Affairs Canada 2017, MVLWB / INAC / GNWT Guidelines for Closure and Reclamation Cost Estimates for Mines, November 2017.

Kinross Gold Corporation 2006, Supplement to Lupin Tailings Containment Area, 2005 Abandonment and Restoration, March 2006.

Kusugak, M 2019, 'Our land, our strength. Reflecting on 20 years of Canada's newest territory, Nunavut', Canadian Geographic, vol. 139, no. 2, March 2019.

Nunavut Water Board 2018, Licence No. 2AM-LUP1520 - Nunavut Water Board (NWB) Decision Regarding Request of Lupin Mines Incorporated (LMI) to Amend the Amount of Security Held under Part C, Item 1 of the Licence and further NWB Guidance regarding the Approval of the Interim Abandonment and Restoration Plan and Closure Cost Estimate under the Licence, Part C, Item 4 and Part I, Item 2.

Ontario Ministry of Energy Northern Development and Mines 2019, Finance Assurance Table, https://www.mndm.gov.on.ca/ en/news/mines-and-minerals/financial-assurance-table 